\title{
The Missions of William Grenville to the Hague and Versailles in 1787
}

THE career of William Grenville, who was to become Lord 1 Grenville and foreign secretary during the latter part of the long administration of the younger Pitt, is so important that it.may be well to give some account here respecting his first diplomatic missions on which we have definite information. As is well known, he was cousin to Pitt, was born in the same year, 1759 , and served in the first ministry of that statesman, as. joint paymaster of the forces. In that capacity he required to know something of the trend of foreign affairs; but the determination to make use of him as special envoy in the two difficult missions in the year 1787 seems to have been due to the sense of confidence which his coolness, common-sense, and freedom from spasmodic impulses universally inspired. The former of these missions, that to the Hague in the month of July 1787 , need not be referred to in detail, partly because I have failed to find the instructions issued to him for that purpose, but mainly because the letters which passed between him and Pitt at that time have been printed in the addenda to the 'Manuscripts of J. B. Fortescue, Esq.,' ${ }^{1}$ commonly known as The Dropmore Papers. Seeing that the second mission was of great importance and was closely connected with that to the Hague, it may be well to present a few introductory remarks, in order to explain the significance of the crisis in the United Provinces which then threatened to bring about war between Great Britain and France, and which Grenville in some measure helped to avert.

The dispute arose, nominally at least, out of the opposing claims of William V, the stadtholder of the United Provinces, and of the democrats, or Pa,triots, with respect to his prerogatives and the relations of the seven component provinces to the central power. The feud was of old standing. The union of those provinces was of the loosest character; and at every time of war, the need of a more centralised administration was urgently felt, while, on the recurrence of peace, the movement of affairs tended in favour of provincial rights. After a period of suppression the stadtholderate was revived in 1747 , and the constitution of 
that year was confirmed in 1766 . Nevertheless the unpopularity of William V, his bias towards England (the land of his mother, Princess Anne, daughter of George II), and his long tatelage under Duke Lewis of Brunswick embittered the dispute, especially as the ill-success of the war with England was laid to his charge. After the signature of the treaty of peace in June 1784 persistent attacks were made against his anthority, and, despite the support skilfully given by Sir James Harris, British envoy at the Hague, they were largely successful. ${ }^{2}$ Neither Prussia nor Great Britain allowed their envoy to give any promise of definite assistance to the Orange party, and, as the Patriots had active support from the French government and its envoy, the marquis de Verac, the stadtholderate seemed in imminent danger. The alliance concluded between France and the United Provinces at Fontainebleau on 10 November 1785 was a decisive victory for the house of Bourbon and left the island power more isolated than ever. The death of Frederick the Great in August 1786 brought to the throne Frederick William II, the brother of the princess of Orange ; but the character of the new monarch blighted her hope of assistance from Berlin. ${ }^{3}$ In the winter of 1786-1787 civil strife broke out in the provinces. That of Holland seemed lost to the Orange party; the free corps raised by the Patriots there and elsewhere had material aid in men and money from France, so Sir James Harris averred; Holland drew a cordon of these armed burghers along its frontier and overthrew the regents, or chief magistrates, of several of its towns where the prince of Orange had the right to nominate them. The province of Utrecht was rent by a schism ; the city of Utrecht and some towns threw off his authority and elected provincial estates, but the rural districts there, as generally, remained faithful; the loyal estates of the province assembled at Amersfoort, while the prince endeevoured to reduce the chief city by force.

Such was the position of affairs. The despatches of Sir James Harris painted it in the darkest colours; but during a visit which he paid to London in May 1787 he friled to convince Pitt of the need of according more active support to the Orange party. All that he gained was the sum of $20,000 l$., subsequently raised to $90,000 l$., for secret service at the Hague. It is probable that this $8.2 m$ of

' See the docaments on this subject edited by H. T. Colenbrander, Do Patriottentijd (appendix to vol. i.); slso the second volume of the Alalnesbury Diaries.

3 Lecky (Hist. of Engl. v. 80) states that the accession of Frederick William made a change in Prussia's relations. I can tind no proof of this in our archives, and there is much that contradicts it. No decisive change is observable until June 1787, when his offer of a joint mediation with France on Dutch affairs was rather curtly repulsed by Montmorin, and he becnme more inclined to act conjointly with England.

4 Malmesbury Diaries, ii. 303-6; Foreign Oftice, Holland, no. 14 : Carmarthen to Harris, 10 Jane 1787. 
money enabled him to reverse a motion carried in the Statesgeneral for the admission of deputies from the illegal (or Patriotic) estates of Utrecht, which, if ratified, would have given to that party a clear majority in the States-general and enabled it to demend military aid from France. The reversal of this vote and the signs of disgust which Frederick William now showed at the rejection by the court of Versailles of his offer of a joint mediation with it in the Dutch disputes seem to have emboldened the princess of Orange to take a step which was to have important consequences. She resolved to depart from Nimeguen, then her residence, and proceed to the Hague, in order to inspirit her supporters. As is well known, she was stopped on the borders of Holland by a body of the free corps, and by an order of the estates of Holland she was compelled to return on 28 June 1787. After examining the British archives of 1787 and the private letters of Harris to Carmarthen I have come to the conclusion that the initiative for this step rested with the princess and not with Harris, as has often been claimed. But the evidence is too complex to be set forth here. It must suffice to say that Frederick William sent a strong demand for satisfaction from the estates of Holland, which was evaded by that body; that Pitt now saw the desirability of supporting Prussia in her demand, but that the British government also had in view a joint intervention along with France and Prussia in the Dutch question.

Hitherto the Pitt ministry had taken few steps towards a rapprochement with Prussia, because the character of her monarch and the actions of Thulemeyer, her envoy at the Hague, had inspired general distrust. The marquị of Carmarthen, foreign secretary in the Pitt cabinet, favoured an alliance with the two imperial courts, and therefore discouraged the efforts put forth, as occasion offered, by Joseph Ewart, our secretary of legation at Berlin, with a view to an Anglo-Prussian compact. Now however the need of a close understanding was obvious. Hertzberg at Berlin ardently desired it, and by degrees he overcame the hindrances thrown in his way by the French party at that court and Count Finckenstein, his colleague at the foreign ministry. The British government encouraged Frederick William to persevere in his demand for reparation for the insult to his family. Its contention was that reparation must be forthcoming before any effort could be made by the three powers towards a peaceful settlement of the disputes; and at first the French government inclined to the same view, or at least did not oppose it. ${ }^{5}$ But when the states of Hollend refused to grant satisfaction, and Prussia began to assemble an expeditionary corps

- Foreign Office, Prussia, no. 11 ; Carmarthen to Eqart, 17 and 27 July 1787. See too the details given by Dr. F. Luck waldt, 'Die Englisch-preussische Allianz von 1788' (in Forschungen sur Brand. und Prezss. Geschichte, 1902) and F. H. Wittichen, Preussen und England in der Europ. Politik, 1785-1788 (Heidelberg 1902), ch. vii-x. 
at Wesel, the court of Versailles remonstrated and threatened to form an equally large camp at Givet. Once more Frederick William wavered, partly from fear of France and Austria, partly from distrust of England; and on 17 July Ewart reported to Carmarthen that the king of Prussia had decided in favour of a joint mediation with France alone in the disputes with the United Provinces. Hertzberg however assured Ewart that he had succeeded in appending to the Prussian proposal conditions with respect to the stadtholderate and reparation for the insult which France was certain to reject. ${ }^{6}$ Such proved to be the case.

Far more critical however was the situation at Versailles. There the signature of the Anglo-French commercial treaty in September 1786, and the personal popularity of William Eden; our special envoy, were valuable influences making for peace. But when the Prussian forces began to assemble at Wesel that court took a high tone, and probably would have opposed Prussia by arms had the States-general at the Hague sent a formal demand for help, or had the condition of the French finances allowed timely and sufficient preparations to be made. We know also from the private letters of Eden to Pitt that Montmorin was strongly averse from a forward policy in Holland, and that Louis XVI held the same view. Other ministers however, notably De Ségur (war) and De Castries (marine), were for vigorous action; but early in August more pacific views prevailed, and France agreed to the British proposal that both powers should suspend the preparations for war and should not resume them without formal notice.

The actual views of ministers are often seen by information which they send to responsible officials far away; and in the Pitt Papers (no. 102) there is a long despatch of 2 August 1787 to Earl Cornwallis, the new governor-general of India, which shows the opinions of the cabinet. It is not signed; but the fact that the foreign office despatches were in that year always dated from Whitehall seems to show thet it was from Pitt himself. As it has been printed in the Cornwallis Papers out of the natural order (namely at i. p. 383, instead of i. p. 279) it may be well to insert it here.

(Private.)

Downing Street : 2 Angugt 1787.

\section{To Earl Cornwallis.}

I think it material as speedily as possible to apprise your lordship confidentially of some circumstances which have lately arisen in consequence of the state of affairs in the United Provinces, which may possibly, though I think not probably, lead to serious consequences.

The measures which have long been parsuing at the instigation of

- Foreign Office, Prassia, no. 11 ; Ewart to Carmarthen, 17 July 1787. See Count Barral de Montferrat's Dix Ans de Paix armee (1893), ch. xiil., xiv., for a version of events hostile to England and Prussia. 
France to abridge the most important rights of the stadholder, if not to deprive him altogether of his office and to ohange in many essential parts the constitution of the republic, have gradually excited a spirit of resistance in the majority of the provinces; and the situation grew so critical towards the beginning of this summer that it seemed probable that the contest would be decided by the sword.

It was impossible for the ministers of this country to be indifferent to the event, as the success of the French party could hardly fail to render the republic so dependent on France as to give that court the absolute disposal of its force and resources. From the maritime strength which it might at least be mode capable of exerting (when acting under the direction of France, who would naturally tarn everything to that object), from its local position, and particularly from that of its dependencies in India, I need not point out to your lordship how much this country would have to apprehend from such an event in any war in which we may be hereafter engaged.

The prospect was the more alarming as France gave open encouragement to her friends in Holland, and there was even an appearance that if they were too weak to carry the point themselves she would support them by force. At the same time the extreme disorder of the French finances (which the proceedings of the Notables had disclosea to the world) and the unsettled state of their government since the death of Monsieur de Vergennes made it very improbable that they would hazard a step which might tend to commit them with other powers. In this situation the king's minister at the Hague (who had been long endeavouring to efface the impressions of resentment towards England and to revive the old system and disposition) was instructed to hold such a language as, without pledging this country, might at least mark the interest we took in what was passing, and show a disposition to interfere, if our protection should be called for, to counteract any open attempt from France, and if the exertions of the well disposed party in the republic, as well as the conduct of other powers in Europe, should afford a prospect of our doing it with effect. The French court grew uneasy at these symptoms, and through the duke of Dorset and Mr. Eden began a communication on the state of affairs in Holland, in consequence of which a good deal of explanation has passed, but which has not yet brought things to any decided point. They bave expressed a strong wish that the disputes in the republic should be amicably settled; have disclaimed any idea of aiming to destroy the power of the stadholder, though their general language seems still to point to a dimination of his power and influence; and they have declared a readiness to act in a mediation jointly with this country if it is desired by the States-general. But it has not yet been ascertained whether the two courts can agree upon such principles as may make it probable that such a joint mediation should answer any good purpose. In the meantime they conceived, or affected to conceive, a jealousy of what they called a naval armament here, which was in fact only preparing a small detachment of our guardships to exercise in the Channel, without any addition to our peace establishment; a measure which has been often taken in time of profound peace, though it certainly was foreseen it might excite attention at 
the present moment. They in consequence geve orders for some preparations in their ports, and they have talked of drawing together a corps of troops near Givet, near the frontiers of the republic.

Mutual explanations have taken place and strong professions of pacifick and friendly sentiments; but in the midst of these a serious degree of jeslousy has been excited; and their assurances respecting their preparations have been so vague that we have just now found it necessary to press for a full eclaircissement; and, if that is not satisfactory, we shall be under the necessity of immediately making every exertion to put ourselves in a state of action. The ides of inviting a joint mediation, and perhaps including in it the emperor and the king of Prussia, has been suggested and in part proceeded apon in Holland; but both parties seem in a great degree waiting the effect of the explanation between this country and France. The king of Prussia, who began his reign with a strong disposition to support the interests of his sister and the house of Orange, but who soon after abandoned them and seemed to have given himself up to the direction of France, has apparently resumed his first sentiments in consequence of an affront lately put on the princess of Orange, who was detained by a military force (under the orders of the province of Holland) as she was on her way to the Hague, and after some confinement obliged to retarn to Nimeguen. He has demanded reparation, and to enforce his demends has ordered a strong body of troops to march.

By the language of his ministers there seems room to hope that he will not content bimself with reparation only for this personal insult, bat will endeavour to maintain the just rights of the stadholder, and with them the constitution and independence of the republic. From his former conduct however this cannot yet be wholly depended upon. The emperor's attention seems chiefly taken ap with the state of the Netherlands, which his attempts to new-model the government have brought to the verge of an insurrection. There is reason however to think that he is rather favourably disposed to the prince of Orange; possibly too he has some suspicion of France fomenting the disorders in his own dominions, and therefore feels the more the interest which he naturally has in the fate of the United Provinces. Your lordship will see by what I have written how much everything at this moment is in suspense; but, from the instructions which have been sent to Paris and to the Hague, as well as to Berlin and Vienna, much of our uncertainty must be cleared up in a very short time. Our great object is to prevent France from taking steps to carry her point in Holland by force. In doing this we wish to aroid as much as possible the risk of a ruptare; and if there is a fair opening to terminate the disputes in the republic safely and honourably by a joint mediation we shall eagerly embrace it. I am much inclined to believe this will be the issue, as I am persuaded France is neither inclined to extremities nor prepared for them; and if the emperor and the king of Prussia respectively take the line which is to be expected there can hardly be a doubt of everything ending quietly and successfully. It is however always possible that things may take a contrary turn, and I have troubled you with this long detail that you may see as accurately as I can state it the nature of our situation, and 
may be prepared for any contingency. The sentiment of security and confidence which I have long felt from the interests of this country in India being under your lordship's direction is a source of peculiar satisfaction at this moment. I trust the effects of your administration have already been such that we have nothing to fear for those possessions in the event of a war. Bombay is the only point for which there has appeared cause to be anxious, and measures have been taken which Mr. Dundas has, I know, explained to you, and from which you will also bear from the secretary at war, which I hope will be effectual and in time.

He adds that if war broke out

France will probably have the support of the province of Holland, and perhaps that of Groningen and Overyssel, while we shall have on our side the remaining provinces, making the majority of the States-general. ... If at the outset of a war we could get possession of the Cape and Trinquamale it would go farther than anything else to decide the fate of the contest.

The hope is then expressed that Cornwallis would strike at Trincomalee, while the Cape would be attacked from England. The relief afforded to India in finance would burden England; but that would be repaid by the added vigour of Cornwallis's actions in India.

In the same packet (no. 102) is another letter, signed by Pitt, to Earl Cornwallis, in which the writer still doubts the probability of war. It will be convenient to present this letter here, in order not to interrupt the nerrative of Mr. Grenville's mission and of its results.

\section{(Private.)}

Downing Street: 28 August 1787.

I send by this conveyance a duplicate of a letter addressed to you by the 'Ranger' packet. Since that time no decisive turn has been given to the situation of affairs. The idea of a mediation in the United Provinces, though proposed some time ago by Holland, and approved by the four provinces in the opposite interest, has not yet been determined upon. It is delayed by Groningen and Overyssel, and perhaps now secretly discouraged by France, who finds the present moment unfavourable to any settlement consistent with her views, [and] wishes probably to gain time. The most explicit assurances bave been given us by France in answer to our inquiries respecting naval preparations, and we have not bitherto found it necessary to go further than the equipment mentioned in my former letter. The camp at Givet has not yet taken place, but it probably may in a very short time, in consequence of the assemblage of Prussian troops at Wesel, which France has in vain endeavoured to prevail upon the king of Prussia to countermand, and which will probably kave taken effect by the first week in September. Holland still persists in not giving the king of Prussia the reparation which he requires, and he will most likely employ his army to enforce it. In the meantime the 
internal violence in the republick increases and makes it difficult to judge what is likely to be the issue. Possibly till the personal reparation to the king of Prussia is adjusted no effectual step can be taken towards the general settlement of the dispate. But, as he is now fully disposed to co-operate in effecting such a settlement on terms perfectly conformable to our wishes, and as the increasing embarrassments in France (from the state of her finances and the resistance of her parlements to the proposed taxes) renders her open interference more and more difficult, there seems reason upon the whole to hope for a favourable termination of the basiness. Every degree of preceution on our part is however still necessary. The orders from the secretary at war for sending a regiment to Bombay, which I alluded to in my former letter, are sent by this convoyance. A duplicate will be sent by the first safe opportunity, as we are extremly anxious for their speedy execution. - I am, \&c.,

IV. Pitr.

$\left.\begin{array}{l}\text { Earl Cornwallis } \\ \text { Sir Arch. Campbell }\end{array}\right\}$ By Vienna.

The situation, then, was very obscure at the beginning of August, when Grenville undertook his mission at the Hague. If we may judge from the letters which he wrote to Pitt (not to Carmarthen, be it observed) he was sent mainly by the prime minister, in order to check the accounts given by Sir James Harris, who had long been on terms of close intimacy with the foreign secretary. The Harris-Carmarthen correspondence, as published in the Malmesbury Diaries, proves that the latter had long been desirous of employing more vigorous measures than those which Pitt had enjoined. That the eager advocacy of the Orange cause by Harris had aroused some suspicion at London is clear from a phrase in a letter of the duke of Dorset, dated 19 July 1787, that Harris 'was playing the devil at the Hague.' $\tau$ It is probable therefore that Grenville, while sent ostensibly in order to gain full information with a view to the proposed joint intervention of England, France, and Prussia in Dutch affairs, was acting also as Pitt's emissary for the purpose of keeping a watch on Sir James Harris. The relations between the two envoys were quite cordial $;^{8}$ but Pitt and Carmarthen were not fully in accord; and the former, having recently taken this question largely into his own hands, as the text of some draft despatches in his handwriting proves, would almost certainly desire to have evidence on which he could absolutely rely. The account which Grenville gave of the constitutions of the several provinces, and of the desirability of somewhat relaxing the règlements which gave to the stadtholder the right of appointing magistrates

' Auckland Journals. 1. 520. The duke of Dorset was our ambassador at the French court, but was then on a long furlough in England.

- Dropmore Papers, iii. 412; see too Professor E. D. Adsms's excellent mono. graph, The Influence of Grenville on I'itl's Foreign Policy, pp. 5, 6. 
in Guelderland, Overyssel, and Utrecht, shows that he saw the reasonableness of the Patriots' contentions, at least in that particular. ' To the ardent mind of Harris that whole movement was the work of French agents and French gold. The differences in the rights of the various provinces and districts and towns made Grenville's inquiry very difficult. He found that the Dutch themselves were often uninformed on these details, and that the strifes arose, in part at least, from this doubt and uncertainty. ${ }^{10}$ After proceeding to Nimeguen, in order to confer with the duke of Brunswick, commander of the Wesel force, Grenville returned to London, where he arrived on, or shortly before, 23 August.

Unfortunately I have found in our archives no account of his interview with the duke of Brunswick, or minutes describing his conference with ministers on his return. But it is significant that on 24 August Carmarthen sent off to Paris, the Hague, and Berlin despatches of great importance, which may have resulted from the information brought by Grenville as to the serious state of affairs in the United Provinces. The decision of ministers, therein expressed, was also based on the alarming reports sent by Harris from the Hague on 20 August as to the advance of a body of the free corps against the Hague, and of their successes in other parts of the land. The arsenal at Delft seemed about to fall into their power. Harris had sent away the British archives, and was preparing with the stadtholder's friends to retire to the Brille, if necessary. The need of preventing the Patriots from gaining complete command of all the resources of the state had already been recognised by Pitt, but he probably waited until Grenville confirmed the news sent by Harris. There are several signs in their letters that Grenville's judgment inspired Pitt with full confidence; and the prime minister seems to have concurred in the adoption of the more vigorous measures adrocated by Carmarthen and Harris. The despatch of 24 August to Eden at Versailles urged that envoy (Dorset being still in England) to protest against the opposition threatened by France to the king of Prussia's attempt to gain reparation from the estates of Holland. The British government (it was stated) fully approved of that attempt, and hoped that it would meet with success without any recourse to extremities; but if reparation should be refused it was perfectly natural that the king of Prassia should take the steps necessary for securing it. France should urge the estates of Holland to grant it, and should then concert measures with the two other powers to secure a cessation of hostilities in the republic, and the disarming of the free corps. The despatches of 24 August sent to the Hague and Berlin were of the same tenour, Ewart

- In his letter of 3 August to the marquis of Buckingham he refers to signs that the king of Prussia was still leaning on France (Buckingham Papers, i. 823).

10 Dropmore Papers, iii. 410, 411. 
being charged to support the Prussian government in its present demand, and secretly to assure it of our support. ${ }^{11}$

The arrival of Carmarthen's despatch at Berlin is said by Ewart to have contributed to the steps taken there on 3 and 4 September, when Frederick William ordered the drafting of an ultimatum to the estates of Hollend and of orders to the duke of Brunswick to prepare for an advance, if, as was nearly certain, those estates refused the Prussian note. They not only refused, but on 9 September drew up an urgent request to the French government for assistance. This in its turn led Montmorin, in his interviews with Eden on 11 and 13 September, to take a high tone. He declared that France was in honour bound to grant that aid, and he accused England of concerting the present action along with Prussia in a sense hostile to France. On 16 September there appeared a Declaration that France would accord help to the province of Holland. Preparations for war were made on both sides, while the Prussians (13 September) crossed the Dutch frontier in support of the stadtholder, advanced without resistance through Guelderland, and easily dispersed the free corps which sought to bar the way in Utrecht and Holland. On 20 September the prince of Orange entered the Hague in triumph, his welcome proving that the Patriots had never gained over the populace in that town. Their resistance was now confined to Amsterdam, which was invested by the duke of Brunswick's forces.

Before the dénouement took place in Holland the British government had resolved to send William Grenville to Paris for the purpose of averting hostilities or of discovering whether they were about to take place. ${ }^{12}$ The instructions drawn up for his guidance, dated 21 September, state that as the main object of his mission. He was further to seek to find a basis of agreement as to some future settlement of Dutch affairs. The need of a complete apology for the insult to the king of Prussia, and the impossibility of allowing France to intervene in a contrary sense, having been clearly explained to the French government, Grenville was to require that the future arrangements in the United Provinces should be such as would restore the constitution of 1747 in its essentials, and would prevent power from falling into the bands of those opposed to British interests. Any opposition of the French government to this demand must be regarded as a sign of hostility to Great Britain. The stadtholder must be restored to the position which he held in 1766, and any change in the reglements of the

1 Foreign Office, France, no. 25; Holland, no. 17 ; Prussia, no. 11.

12 George III., in a letter to Pitt of 16 September, suggested that someone should be sent to Paris who could deal with the French Ministers better than Eden did (Pitt Papers, Public Record Office, No. 103). Grenville was certninly chosen by Pitt. See, too, Buckingham Papers, i. 326-8. 
three provinces named above must be referred to the free deliberation of their estates. Grenville was finally required to discourage any attempt to protract the discussions and to bring them to a point as soon as possible. ${ }^{\text {is }}$

The views of the British cabinet are also set forth in Carmarthen's despatch of 19 September, to William Eden at Paris, of which the following summary may be given :-

No. 83.

To Mr. Eḋen.

Whitelall : 19 September 1787.

His majesty learns with the utmost regret the determination of the French court; he desires to see the disputes in Holland peacefully settled; but it is impossible to remain a quiet spectator to any armed interference on the part of France. The conduct of England has been consistent and sincere: she has not pressed Prussia to intervene (a.s was insinuated), though she approved of her intervention, without wishing that it should proceed to extremities. France can have no just ground for opposing the intervention of Prussia. However much France has sought to induce the estates of Holland to give reparation for the insult no reparation has been forthcoming to his Prussian majesty. The Dutch estateg-general, it is true, have declared the wish to give reparation; and if France intervened she would be supporting a party acting in contradiction to the estates, and to the past recommendation of the French court itself. H.M. must now make preparations to resist French intervention if it takes place, but he sincerely desires to avert war. As far back as 14 August he (Carmarthen) stated to Eden the principles to be adopted as the basis of a mediation; but no official answer has been received to that communication. The excesses of the free corps make it impossible to protract the discussions on this matter, but the mediating powers should at once consult together to control those excesses. This is a sine qua non towards the settlement of the disputes. Only the lawful troops of the United Provinces should be allowed there. The restoration of the prince of Orange to his powers must also be a condition and basis of the settlement. ${ }^{14}$

It may be well to quote from the shorter but equally important despatch of Carmarthen to Harris at the Hague, also dated 24 August. After observing that news from the Hague was awaited with much impatience it stated that orders had recently been given to prepare forty sail of the line for sea. This statement, it may be noted, controverts that of the editor of the Malmesbury Memoirs (ii. 399, note 2), that on or before

13 Foreign Office, France, no. 26. See too E. D. Adams, op. cit. pp. 6, 7. I cannot however agree with Mr. Adams in thinking that there was any substantial difference of opinion between Pitt and Grenville with respect to obtaining a guarantee from France that she would recognise the restorstion of the stadtholder's powers and the Dutch constitution of 1766. Pitt mentioned that as his own opinion very tentatively; and evidently Grenville favoured the other alternative, of letting France drop ont altogether, becsuse in the interval, by 26 September, he had heard news of the decisive success at the Hagae (Dropnore Papers, iii. 428, 481).

14 Foreign Office, France, no. 26. 
20 July Carmarthen promised to arm forty line-of-battle ships for the support of Prussia. No movement of the kind was made before the middle of September, when matters first began to look threatening. ${ }^{15}$ The despatch of 24 August proceeds thus :-

No. 98.

His majesty is persuaded the occasion requires a perseverance in the firm and temperate language uniformly held to the court of France, accompanied by such measures as show that H.M. is preparing to act with effect if France persists in her determination. This conduct on the part of H.M. and the apparent want of preparation and the many embarrassments of the French court make it possible that, when they find a orisis is unavoidable, they may determine to give way in substantial points rather than risk the consequences of a contest. There is no doubt that such an issue to the business is on every account the most desirable; but if it is to take place it must be immediate, as, after things have been brought to the point where they now are, H.M. cannot suffer himself to be amused by negotiations which may perhaps have no other view but to gain time. In order to discover, if possible, the real sentiments of France on this subject the ling has determined to send Mr. Grenville immediately with a epecial commission to Paris. The information he has had the opportunity of acquiring in Holland and his knowledge of the present sentiments of H.M.'s confidential servants peculiarly qualify him for this trust. You will perceive from his instructions, as well as from what I have already stated, that he is to endeavour, if possible, to bring the French court to such a distinct and positive agreement on the several points of discussion as may lay the foundations of a compleat settlement without deley. It is H.M.'s wish to show a disposition to give France every possible facility as to the mode, provided the objects are obtained. . . . 16

The closing part of Carmarthen's despatch of 23 September to Harris is also worthy of quotation. At that time favourable news as to the Prussian advance and the collapse of the Patriots had reached Whitehall from the Hague, and a despatch from Eden also seemed to show that France would not push matters to extremes. After noticing this news Carmarthen proceeded in these terms:-

But it is time to consider how any advantages the prince of Orange may have gained may be best and most permanently secured. Notwithetanding the blow which is now happily given to the influence of France in that country, yet from considering the means she may possess of disturbing on some fature occasion the system whioh seems now likely to be established, and from the desire to lay the foundation, if possible of permanent peace, perhaps the best way of securing the interests both of the stadholder and his family for the future would be still to take the

16 For the activity in naval affairs since 1783 see Joumals of Sir.T. Byam Martin, iii. 380_B (Navy Records Society).

16 Foreign Office, Holland, no. 18.

VOL. XXIV. - NO. XCTV. 
participation and concurrence of France in the settlement, if she should be willing to agres to it on such terms as are proper under all the circumstances. ${ }^{17}$

The despatches prove that a joint mediation of the three powers in the United Provinces was still the aim of statesmen at Westminster, and it is probable that if France had acquiesced in the new situation of affairs that event might still have occurred, though with far less of advantage to the Patriots than France had hitherto contemplated. We torn however from these speculations to consider the course of Grenville's mission. After landing at Calais he received Pitt's letter of 21 September containing news of the successes of the Prussians and the dispersal of the Patriots at the beginning of that so-called campaign. ${ }^{18}$ Those letters having been printed in the Dropmore Papers (iii. 426) we need consider here only the reply of Grenville. Pitt had advised him to be as conciliatory as possible to Montmorin, and Grenville evidently concurred.

Calais: 28 September 1787.

My dear Pitt,-I received your letter just as I was setting out for Paris. There seems occasion to hope that our friends have for the first time known how to avail themselves of a crisis favourable to them, and that the consternation of our enemies is at least as great as that of the prince's friends has ever been.

I had alrasdy, in ruminating on the subject, anticipated in my own mind the restoration of the stadholder and of the dismissed regents in the different towns which had surrendered. ${ }^{19}$ The conclusion which I drew from this with respect to the language to be held to Montmorin was nearly the same with that you mention, except that I think there will be a real difficulty in stipulating the doing that which is already done, and which our friends will probably never be brought to acknowledge as done illegally. And certainly with respect to the regents it will (I should think) be sufficient now to adhere to the old proposel for the deliberation, adding only some such word as 'ancient'-according to the forms of their ancient constitution.

I cannot however help thinking that Montmorin will tell me with truth that this is not the moment for France to negotiate, and that any one, the smallest, concession would be more disgraceful to her now than the giving up overything would have been a week ago.

This success will make our friends very untractable on the point of amnesty and concessions. The former particularly I am sure they will make great difficulties about, and I shall think it right to say nothing upon it till I hear more from you, especially as notbing has been said to Harris about it.

17 Foreign Office, Holland, no. 18.

1s For details soe P. de Witt, Une Invasion prussientre en Hollande on 1787 (Рaris, 1886).

12 The regents, or chief magistrates, of several Datch towns had been forcibly deposed by the tree corps. 
I have not time to add any more, as the packet is sailing. Believe me ever

Most sincerely and affectionately yours, W. W. GrenviLLe. 20

On arriving at Paris he heard tidings of the diplomatic triumph which Harris had gained at the Hague on 21 September, when he induced the Estates of Holland to cancel their recent legislation limiting the stadtholder's powers, and to reverse their appeal of 9 September for armed help from France. This event deprived the court of Versailles of all diplomatic ground for intervention and greatly simplified Grenville's task. Nevertheless in his interview of 28 September with Montmorin he found that minister very reserved. Montmorin declared that, whatever understanding there might have been between Great Britain and France with respect to a joint mediation in the United Provinces, the situation was now materially altered by the presence of 25,000 Prussians in that country. Before any negotiations for that purpose could proceed the Prussians must retire. As for the Déclaration issued by the French government on 16 September, to the effect that it would grant the military aid asked by the province of Holland, he (Montmorin) declined to withdraw it antil those troops withdrew. He made the same stipulation a sine qua non for the concession of the point, on which Grenville pressed him as hard as he could, namely that Great Britain and France should agree to suspend their preparations for war; but Grenville replied that he could not with propriety venture to discuss the subject of the evacuation of the United Provinces by the Prassians, and that the preliminaries of a settlement of the Dutch question should be arrived at before they retired. To this Montmorin rejoined by inviting him to indicate the basis of a scheme of pacification, but Grenville declined this as being beyond the scope of his duties." We may add that Pitt subsequently approved his caution in this matter.

The course of this interview afforded little hope of arriving at an agreement, and the prospect was left equally doubtful by an interview on 1 October. Eden, in a despatch (no. 95) of 28 September, expressed the fear that France would make war if the Prussians did not speedily retire and if a settlement were not soon arrived at in a conciliatory way. ${ }^{31}$ The friendly relations subsisting between Eden and Montmorin warranted the hope that his (Eden's) presence at the next interview would lead to a more definite result; but it did not. Montmorin enclosed himself in the same formula as before-that France protested against the presence of the Prussians in the United Provinces and conld make no promise whatever respecting her conduct as long as they remained

- Pitt Papers, Public Record Office, no. 140. "21 Auckland Corrospondence, i. 208. 
there. Grenville therefore determined to return to London, so as to inform the cabinet of the attitude of the French government. In point of fact even before the first interview with Montmorin he had divined the secret, which he expressed in his letter to Carmarthen, dated Paris, 27 September-that it was probable that France would ' withdraw herself wholly from the business, leaving to Great Britain without a contest the important and satisfactory advantages to be derived from the late settlement of affairs in Holland.' ${ }^{28}$ This perhaps was too sanguine and somerhat premature. For some days the French government shrouded its actions in a reserve which left both the British and Prussian governments in a state of suspense. There was the possibility that Spain would support France in case the latter decided to risk a war; or that Austria would fulfil her treaty obligations under the Kaunitz system. But the former was crippled by debt, and the court of Vienna had recently been distracted by the declaration of war by the sultan against Russia. The informal but nevertheless binding compact subsisting between Joseph II and and Catharine II bound him to help her in case of attack by another power; and it was unlikely that Austria would venture to attack Prussia while hostilities against the Porte were imminent. It is stated by Ewart in his despatch of 8 September to Carmarthen that Prussia would scarcely have ventured on her expedition against Holland if the news of the outbreak of the eastern war had not reached Berlin on 7 September. Even the Francophile minister Count Finckenstein withdrew his opposition to that measure when he heard of the news from Constantinople. ${ }^{23}$ Montmorin also admitted to Eden on 11 September that the events in the east were a cause of perplexity and embarrassment to France. ${ }^{24}$

Grenville therefore argued on many data which are not obvious now unless we take a wide view of contemporary events. The turn of the wheel in the east deprived France of help from Austria and set Prussia free for energetic action in Holland. ${ }^{25}$ The skill of Harris in inducing the estates of that province to repudiate their previous appeal for help from the court of Versailles deprived it of diplomatic grounds for intervention, and, most of all, perhaps, the financial and political crisis in France and the advent to almost dictatorial power of Loménie de Brienne, archbishop of Toulouse, a firm friend of peace, decided the French cabinet to do nothing in

7 Foreign Office, France, no. 26.

"Foreign Office, France, no. 26. The statement corrects a curious conjecture of Count Barral de Montferrat, op. cit. ch. xiii. ad fin.

z The despatches of Sir Robert Marray Keith, our ambassador at Vienna, show that the French Court in October 1787 made pressing requests for help from its ally; but the latter had resented the action of France in Dutch affairs in 1785, and was now beset by the demands of Catharine for armed assistance against the Turks. An evasive reply was therefore sent to Paris. 
the United Provinces, and, while protesting against the action of the Prussians, to allow French influence in that land to lapse. The news of the surrender of Amsterdam on 10 October is said to have put an end to the last efforts of the war party at the court of Versailles, and on 27 October Montmorin exchanged with the duke of Dorset and Eden declarations by which Great Britain and France agreed to disarm, and the French government added that it had never intended to interfere by force in the affairs of the United Provinces, et qu'elle ne conserve nulle part aucune vue hostile relativement à ce qui s'est passé en Hollande. ${ }^{26}$

It may be well to conclude this article with a despatch of Eden to the marquis of Carmarthen, which throws an interesting light on the decision of the French government not to have recourse to arms. Had it drawn the sword, events must bave gone very differently. The influence of Loménie de Brienne will be noted.

(Separate and Secret.)

\section{Eden to Carmarthen.}

Sève [Sèrres] : 1 November 1787.

My lord,-I had a long conference with M. de Montmorin on Monday morning, and many circumstances occurred material to be stated to your lordship.

He expressed with earnestness his satisfaction at the mention of pacific appearances between the two courts, and was very obliging in his expressions respecting the manner in which the instructions of his majesty's ministers had been executed, so as to aid him essentially in accomplishing so great a work. He then told me that in the course of our discussions this country had been much nearer going to war than from a view of the circumstances I might suppose. He said that, exclusive of all objects of external interest, there had been some opinions of weight that $\mathrm{a}$ war was the best mode of finishing the internal troubles ${ }^{27}$ which had prevailed at the time of the king of Prussia's march; that there were others also hardy enough to think that, if such a convulsion should break the credit of France, it would also shake that of Great Britain, and that the effect would eventually be of less comparative importance to this country then to us. He talked with due disregard of such speculations, but he said that there was one moment in which a measure had nearly been taken which he was confident must have prevented what has bappened in Holland, and which, tho' it might have risqued an immediate war with England, would perhaps have ended in an accommodation infinitely less injurious to the French interests than what has now taken place; and he seemed to intimate that he had advised this measure in council, but had been overruled. This was the forming the camp at Givet upon the first news of the Prussian march towards Wesel, ${ }^{28}$ notwithstanding our remonstrances and menaces. In

2 Auckland Correspondence, i. 255-8; Annual Register, 1787, p. 283.

7 The tronbles between the French government and the Paris parlement are referred to.

2* I.e. early in July 1787. 
parsuing this subject he said that he had no blame to impute to himself, except perhaps that natural weakness of mind which had prevented his recalling $M$. de Vérac from an important station for which he was evidently unfit. That he had utterly disapproved the French pursuit in Holland, from the moment in which he saw to what degree France was committed in it; and that, after having opened to me in July his disposition to get clear of it, he never could bring the business to any point with M. de Verrac, and from motives of personal tenderness had taken the resolution of recalling him a few weeks too late. ${ }^{29}$ He was candid in avowing that the wisdom and firmness of conduct maintained by his majesty and his councils in the whole transaction, accompanied and closed as it hed been by full success, bore a character which would make a lasting impression not merely in bistory but in the future politics of Europe.

Montmorin then asked Eden whether it had been proposed at London to make strong and unreasonable demands from France. To this Eden replied that he believed not; that his majesty had kept within the lines of rectitude and would never urge le droit du plus fort. Eden added that if war had occurred strong demands would certainly have been made at the end of it. Montmorin replied that the rumour of some further demands had led France to arm at an expense of from twenty-five to thirty million francs; and, if such demands had been made, France would at once bave gone to war. Montmorin then added that he would instantly stop the reinforcements about to be sent to French foreign possessions; that he would gladly give information as to military and naval movements in foreign parts which could prevent 'uneasiness and expense'; that the two governments ought to give each other information frankly. He said he had heard of a plan of England to seize the East India possessions of France. Eden replied that he did not believe that we had taken any measures other than precautionary. Montmorin then sought to have an understanding about naval forces on the North American station and elsewhere. Eden could not answer this; neither could he inform him what plans might be made for our usual peace establishment of the navy. The French minister then said that the Turkish business was serious, but could not embroil England and France. The emperor would probably try to acquire Moldavia and Wallachia, and the empress Catharine, Oksakoff and one or two other places; but Constantinople would not be touched. Eden concluded his despatch as follows :-

The archérêque de Toulouse [Loménie de Brienne] on Tuesday last expressed to $\mathrm{me}$ in the presence of several of the foreign ministers the

2 Count Barral de Montferrat, op. cit. ch. xiii., proves that the resolution to recall the meddlesome and intriguing French ambsssador at the Hagae, De Verrac, was formed on 20 Angust: the recall took effect on 81 August. 
strongest satisfaction at the business of the preceding Saturday; and he afterwards repeated to me that he entertained great hopes of our having at length laid the foundation of a long period of peace. Many people however feel differently about the transaction, and their mortification will be increased when the Declarations are published.

I have, \&c.,

W M. EDEN. ${ }^{30}$

The publication of the Contre-Déclaration, so damaging to the prestige of France, was natarally followed by the collapse of her influence in the United Provinces, the substitution of that of Great Britain and Prussia, and the signature by those two powers of treaties with the Dutch republic and between themselves. With these later developments we have no concern; but they formed a brilliant sequel to the events here considered, in which Grenville played no unimportant part, and at the age of twenty-six displayed the coolness and perspicacity of manhood.

J. Holland Roge.

- Foreign Office, France, no. 26. 